\title{
THE AUTHORITY OF ADMINISTRATIVE COURT IN SETTLING THE DISPUTES OVER ELECTION PROCESS IN INDONESIA
}

\author{
Oce Madril ${ }^{1}$ \\ ${ }^{1}$ Faculty of Law, Universitas Gadjah Mada \\ Email: ocemadril@ugm.ac.id
}

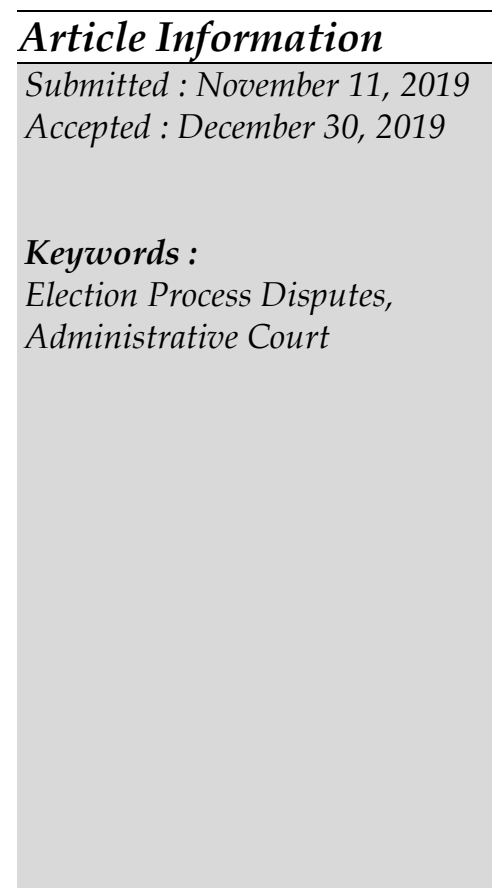

\begin{abstract}
Indonesia is a country that provides constitutional guarantees over the principle of popular sovereignty. A manifestation of the principle of popular sovereignty is through the holding of a General Election. To safeguard the implementation of fair and democratic elections, laws and regulations concerning elections are made by the government. One of the principles of fair and democratic elections is the availability of legal mechanisms to resolve election disputes. The Indonesian Election Law already has these rules. One mechanism for resolving election disputes is through state administrative courts. This research focuses on discussing the development of the authority of the State Administrative Court (PTUN) in resolving disputes over the Election process. The PTUN has long been established in Indonesia, but the authority of the PTUN in resolving election disputes is a new authority expressly granted by the post-reform election law. This study also discussing two PTUN decisions. The decisions show how electoral law is applied in the practice, which is sometimes not always the same as what is expected by legislators.
\end{abstract}

\section{Introduction}

Indonesia is a country that provides constitutional guarantees to the principle of popular sovereignty which embodies the adage "vox populi vox dei" (the voice of the people is the voice of God) (Ni'matul Huda, 2012: 169). This is stated in Article 1 Paragraph (2) of the 1945 Constitution of the Republic of Indonesia (hereinafter to as UUD 1945) which states that "Sovereignty is in the hands of the people and is carried out according to the Constitution". One embodiment of the principle of popular sovereignty is through the General Elections (Elections). Elections are a democratic way to form and transfer power from the people to state authorities, as the International Commission of Jurist formulated in its conference in Bangkok in 1965 that:

"Representation government is a government deriving its power and authority from the people which power and authority are exercised through representative freely chosen and responsible to them."

In Indonesia, elections are constitutionally regulated in the provisions of Article 22E of the 1945 Constitution. The provisions state that elections are held directly, publicly, freely, confidentially, honestly and fairly. According to Jimly Asshiddiqqie (2012: 276), one of the objectives of the General Election is to exercise popular sovereignty in representative institutions. Meanwhile, according to Muktie Fajar (2013: 28), the General 
Election is the most important institution for the fulfillment of three basic principles of democracy in a republican government, namely people's sovereignty, the legitimacy of government, and the change of government regularly, so that the mechanism for filling the positions of people's representatives such as the DPR, The DPD and DPRD is carried out through direct involvement of the people in an election process.

To safeguard these principles and ensure that people's sovereignty can be carried out as they should, the holding of elections must be following its objectives. Every democratic government should be able to hold elections democratically as well because it is an important pillar in a modern democracy (Jimly Asshiddiqqie, 2013: 11). This means that there must be a clear and precise mechanism and regulation regarding the implementation of the General Election so that the election is carried out based on democratic principles.

Tracing the history of Indonesian state administration, from 1945 to 2019, Indonesia has held 12 (twelve) elections. The first elections were held after ten years of independence, in 1955. Not only once, under the 1950 Provisional Constitution, but elections were also held twice: September 29, 1955, to elect members of the DPR and December 15, 1955, to elect Constituent Assembly members. Under the New Order regime, elections were first held in 1971. Despite all the controversy regarding election results, elections in the New Order period were held regularly every five years (Refly Harun, 2016: V). Then, the first election in the reform era was held in 1999 and the elections are held regularly every five years. Since the 2004 elections, elections have been conducted not only to elect members of the House of Representative (hereinafter referred to as DPR) and the Regional House of Representative (hereinafter referred to as DPRD) but also to elect members of the Regional Representative Council (hereinafter referred to as DPD). The 2004 election was also the first election for the direct election of President and Vice President.

Aside from being a manifestation of people's sovereignty, elections are also an arena of competition for political parties to see how far they have carried out their functions and roles (Didik Sukriono, 2009: 11). In a competition, of course, there will be competition to be a winner. With the current electoral system and many participants in the election (political parties and individuals), making the election very vulnerable to violations and deviations. Every political party and individual participant will strive to be the winner. The tight competition among election participants requires a monitoring mechanism from an institution guaranteed by law so that the election runs according to existing rules.

To resolve the problems that arise in holding elections, a dispute resolution mechanism is needed. In Indonesia, election dispute resolution is carried out by 2 (two) judicial institutions. Firstly, the State Administrative Court / Pengadilan Tata Usaha Negara (hereinafter to PTUN) to settle disputes over the electoral process. Secondly, the Constitutional Court to resolve disputes over election results. This paper will focus on discussing one mechanism for electoral dispute resolution, namely electoral dispute resolution by PTUN. The discussion is limited to the issue of the development of PTUN's authority in resolving disputes in the electoral process and discussion of PTUN decisions regarding election process disputes. 
There are two main problems discussed in this paper. Firstly, in general, how is the development of the authority of the State Administrative Court in handling disputes of the election process after the reform? Secondly, specifically, how the State Administrative Court resolves disputes over the electoral process. Related to the second problem, there are two cases that will be discussed in this paper, namely first, the case relating to the participation of political parties in the election. Second, cases related to the nomination of DPD members.

\section{Research Methods}

This research is legal research. According to F. Sugeng Istanto, legal research is research that is applied specifically in the field of studying law. The type of research is normative legal research. There are three main approaches used in this study. Firstly, the statutory approach. This approach is carried out by examining the laws and regulations concerning general elections, specifically the provisions relating to the resolution of disputes in the electoral process. Secondly, the historical approach. This approach is used to examine the development of the authority of the State Administrative Court in resolving disputes over the electoral process. Thirdly, the case approach. This approach is carried out by analyzing PTUN decisions related to election process disputes. There are 2 (two) decisions analyzed in this study. Firstly, the case relating to the participation of the Indonesian Justice and Unity Party/Partai Keadilan dan Persatuan Indonesia ( hereinafter to $P K P I$ ) in the election of 2019. Secondly, the case related to the nomination of Oesman Sapta Odang (OSO) as DPD members.

\section{Research Result and Discussion}

\section{A. PTUN and Election Process Dispute Resolution; a conceptual framework}

State Administrative Court (hereinafter to as PTUN) is one of the executors of judicial power for people seeking justice against state administrative disputes. PTUN as a sub-system of judicial power in Indonesia has a function to supervise state administrative actions that harm the people, which also contains legal protection functions for the people in the rule of law (rechtsstaat) (W. Riawan Tjandra, 2009).

PTUN has the authority to examine, decide upon, and resolve state administrative disputes. According to Law no. 51 of 2009 concerning PTUN, State Administration Dispute referred to in statutory regulations is a dispute arising in the field of State Administration between a civil person or legal entity and the State Administration Agency or Officer, both at the central and regional levels, as a result of the issuance State Administrative Decrees. The object of a state administration dispute is a Government Administration Decree, which is a written decree issued by a Government Agency and/or Officer in the administration of government (according to Law number 30 of 2014 concerning government administration).

In conducting elections, there are many legal issues. Election legal issues can be grouped into several types, namely (1) Election Administration Violations, (2) Election Administration Disputes, (3) Election Results Disputes, (4) Election Organizers Code of Ethics Violations, (5) Election Crime, and (6) judicial review of 
election regulations (Mukthie Fadjar, 2013, Topo Santoso, 2015 and Refly Harun, 2016). Meanwhile, according to Denis Petit (2000:5), the fundamental issues in election dispute resolution theories are (1) the validity of the result, (2) the administrative action of election officials to correct a problem, (3) criminal prosecution against those who have corrupted or attempted to corrupt the election process.

With regard to the electoral legal issues mentioned above, PTUN is only authorized to settle disputes over the electoral process. The dispute resolution mechanism at PTUN can be adopted after the parties have taken administrative efforts at Bawaslu (Election Oversight Body), with the nature of the final and binding decision. Regarding what is meant by the electoral process dispute, it can be found in the Election Law which in essence is a dispute that occurs between election participants and the dispute between election participants and election commission (election organizer) as a result of the issuance of election commission (hereinafter to as $K P U$ ) decisions.

In some literature, this election process dispute is usually referred to as preelection disputes. What is meant by pre-election disputes is the resolution of all disputes relating to the electoral process, whether handled by the election administration, judiciary, law enforcement or any other competent institution. Disputes may concern any election-related area, such as voter and candidate registration, campaigning, conduct of election day procedures or election offenses, and can be lodged against any election stakeholder, including relevant authorities, candidates, media regulatory bodies and others (OSCE ODIHR, 2019: 7).

Election dispute resolution systems are established to ensure the integrity of the electoral process. Through the electoral dispute resolution system, actions taken in the electoral process that are against the law can be nullified or changed through the process of filing a lawsuit. Corrective election lawsuits function to ensure the election process is carried out in accordance with the law; so that mistakes or irregularities in elections can be known, changed, nullified or corrected; and so that suffrage can be guaranteed or restored (IDEA, 2010: 13).

There are no international standards regarding the mechanism of dispute resolution in the electoral process and there is no clearly established consensus in the international community on common standards for a "fair, effective, impartial and timely" resolution of election disputes. Obviously, there is no single method that is equally suited to all countries. Which model is endorsed largely depends upon the degree of consolidation reached in the democratic process (Denis Petit, 2000: 6).

Research conducted by Katherine Ellena (Katherine Ellena et al, 2017: 9-11), shows that each country has a mechanism for resolving disputes over the electoral process. There are six countries examined in their research to see the comparison of institutions authorized to resolve disputes in the electoral process, that are: Mexico, Tunisia, Kenya, Macedonia, Kosovo, and the Philippines. The countries that have permanent electoral tribunals are Mexico and Kosovo. Mexico uses the Electoral Tribunal of the Federal Judicial Branch with a Superior Court in Mexico City and six permanent regional or specialized courts. In Kosovo, the electoral dispute 
resolution process is managed by the Electoral Complaints and Appeals Panel. Then, three countries have a mixed system. Kenya uses the Independent Electoral and Boundaries Commission, judiciary (High Court, Court of Appeal, and Supreme Court) and The Political Parties Disputes Tribunal specifically for disputes between political parties, party members, candidates and coalitions. Philippines with Commission on Elections (COMELEC) and Supreme Court (Presidential Election Tribunal) for Presidential or Vice Presidential elections. Macedonia empowers the State Election Commission (SEC) to address electoral complaints and disputes. Then the Administrative Court, has appellate jurisdiction over the rulings of the SEC. Finally, only Tunisia uses regular courts (Courts of First Instance) to resolve election process disputes and the Administrative Tribunal acts as an appeals court for electoral disputes.

In Indonesia, election disputes can be divided into 2 types, disputes over the electoral process and disputes over election results. Election process disputes are handled by administrative court. Whereas disputes over election results are settled by the Constitutional Court. It could be said that Indonesia also uses a mixed system, because there is a role of Bawaslu (election oversight body) before the case is brought to the administrative court. And as in Macedonia and Tunisia, administrative court plays a role at the appellate level after the dispute is resolved in Bawaslu.

The use of the term "election process disputes" is a new nomenclature introduced by the 2017 Election Law. In the 2012 election law, the term used is "election administration disputes". The definitions used by the two laws are also different. In the 2012 Law, Election Administration Dispute is a dispute arising in the field of election administration between candidates for members of the $D P R, D P D$, Provincial $D P R D$, Regency/City DPRD, or political parties participating in the general election with KPU, Provincial KPU and City/Regency KPU (election commission). Whereas election process disputes, according to Article 466 of Law No. 7 of 2017 concerning Elections, is a dispute that occurs between election participants and dispute between election participant and election organizers as a result of the issuance of election commission (KPU/KPUD) decisions. In the definition of election process disputes (the 2017 Election Law), the parties to the dispute are (1) between election participants, and (2) election participants and the election organizer. Election participants consist of (1) political parties for the election of DPR and DPRD members, (2) individuals for the election of DPD members, and (3) pair of candidates proposed by political parties/joint political parties for presidential and vice-presidential elections.

Election dispute resolution system functions to maintain the legality of the electoral process and to ensure that elections take place in accordance with the principles set out in the constitution and laws. Challenging an election, its conduct or its results may reveal existing weaknesses in the system, but it may also be an indication of the vitality and openness of the political system. Where participants of the electoral process are aware of the opportunities to challenge election violations and those challenges are managed in respect of the principle of the rule of law, there is significantly more confidence in the electoral process. (OSCE ODIHR, 2019: 7) 


\section{B. The Development of the Authority of the State Administrative Court in Resolving Disputes in the Election Process}

\section{General Elections in 1999, 2004 and 2009}

In the 1999 general election, the authority to resolve disputes arising in the holding of the general election was resolved by the Election Oversight Committee (Panwas). This is regulated in the provision of Article 26 (b) of Law Number 3 of 1999 concerning General Elections. The 1999 Election Law does not regulate the involvement of the administrative court in electoral dispute resolution. There is no involvement of the state administrative court or the state administrative high court. If a dispute occurs in organizing an election, the authority to settle the dispute rests with the election supervisory body (Panwas). The authority of the Supervisory Committee also includes handling election violations, before being forwarded to law enforcement agencies.

Notwithstanding the judiciary is not involved, there is an element of the judiciary in the composition of the Panwas members. Judges are one of the mandatory elements in the supervisory committee membership, both at the central, provincial and city levels. As stipulated in the provisions of Article 24 paragraph (3) of Law 3/1999 that the membership of the Central, Provincial and City Election Supervisory Committee, consists of judges, higher education representatives, and community elements. The composition of the Supervisory Committee at the central level is determined by the Chief Justice of the Supreme Court. Whereas for the province is determined by the Chair of the High Court and for district/city level are determined by the Head of the District Court. Then, related to the relationship and working procedures between the Supervisory Committee and the Election Commission set by the Supreme Court in consultation with the Election Commission.

As is the 1999 election, in the 2004 general election, the election dispute resolution was settled by the Election Oversight Committee. This is regulated in Article 122 paragraph (1) letter c of Law Number 12 of 2003 concerning General Elections of Members of the House of Representative, the Regional Representative Council, and the Regional People's Representative Council, that one of the duties and authority of the election supervisor is to resolve disputes that arise in organizing elections. The difference with the Supervisory Committee in 1999 was that the membership elements of the Election Supervisory Committee were more diverse. The Supervisory Committee element in the 2004 election consists of the Police, Prosecutor, Universities, community leaders, and the press.

The settlement of disputes in the holding of elections according to the 2004 Election Law is carried out in various stages. First, when there is a dispute request, the Supervisory Committee brings together the disputing parties for deliberation and consensus. Second, if deliberations and consensus are not reached, Panwas offers alternative solutions to the parties. Third, if the alternative dispute resolution proposed by the Supervisory Committee is not approved by the parties, then the Supervisory Committee makes a final and binding decision. The settlement of the dispute by the Supervisory Committee 
is limited to a certain time. Provisions of Article 129 paragraph (2) of Law No. $12 / 2003$ regulates that the dispute resolution by the Supervisory Committee is conducted no later than 14 days, counting from the disputing parties were brought together.

Then, related to disputes in the holding of the election of President and Vice President (Pilpres), the resolution is also carried out by the Election Supervisory Committee. This refers to the provisions of Article 77 number 1 letter c of Law Number 23 of 2003 concerning the Election of President and Vice President. Furthermore, in the 2009 Election, Law Number 10 of 2008 which became the basis for the implementation of the 2009 Election did not explicitly regulate the administrative court's authority in the resolution of election disputes. Even in this law, there are no clear regulations related to the resolution of election disputes. In Chapter XX of Law No. 10 of 2008, only regulates two main points, namely the resolution of election violations and disputes over election results which are the authority of the Constitutional Court. Law No. 10 of 2008 does not regulate electoral dispute resolution or election administration disputes, as found in the 1999 and 2004 election laws.

Likewise, with the election of President and Vice President, the regulation of election administration disputes, or election process disputes are not clearly regulated in Law No. 42 of 2008 which became the legal basis for the election of President and Vice President. Law 42/2008 only regulates the settlement of Presidential Election violations and the resolution of disputes over the Presidential Election results. Regulations regarding the resolution of disputes over election administration are implicitly found in Law Number 22 of 2007 concerning Election Organizer. As regulated in Article 78 paragraph (1) of Law 22/2007, one of the tasks of the Election Supervisory Committee is to resolve findings and reports on election disputes that do not contain elements of a criminal offense. Thus, from the explanation above it can be seen that from the first election after reform (1999) to the 2009 elections, the dispute resolution mechanism of election administration was resolved by a supervisory body, called the Election Oversight Committee. This institution is not a judiciary but functions as a quasi-judicial institution.

\section{General Election in 2014 and 2019}

The changes took place in the implementation of the 2014 and 2019 elections. In these elections, the administrative court was involved in the resolution of election disputes. The terminology used is election administration disputes. The administrative court involved in election administrative disputes is the State Administrative High Court (PTTUN) for the first instance. Then, legal remedies can be submitted to the Supreme Court, whose decisions are final and binding.

In Article 268 paragraph (1) of Law 8/ 2012 state that election administrative disputes are defined as disputes arising in the electoral administration field between candidates for $D P R, D P D$, Provincial DPRD, Regency/City DPRD, or political parties with the KPU (election commission), Provincial KPU, and 
Regency/City KPU as a result of the issuance of $K P U$, Provincial KPU, and Regency/City KPU decisions.

From this definition, there are only two subjects that can file lawsuits on election administrative disputes. First, candidates for legislative members, both at the DPR, Provincial DPRD, and Regency/City DPRD levels, including $D P D$ candidate members. Second, the political party candidates for election participants. The object of the election administrative dispute is the decision of the KPU, Provincial KPU, and Regency / City KPU. Furthermore, the scope of the election administrative disputes is, first, a dispute occurs between the $K P U$ and the political party (candidates for election participant) which is not pass the verification as a result of the issuance of the KPU's decision on the determination of the political parties participating in the election. Second, disputes arising between $K P U$, Provincial $K P U$, and Regency/City KPU with $D P R, D P D$, Provincial DPRD, and regency/city DPRD candidates who were crossed from the permanent candidate list as a result of the issuance of the KPU Decree concerning the permanent candidate list.

Looking at the scope of the second dispute, it appears that this arrangement provides an opportunity for legislative candidates to submit disputes directly if a candidate feels disadvantaged by the KPU's decision. If consistent with the concept of election participant, that is a political party, then only political parties that have legal standing to sue in representing the interests of the candidates. Since the participants in the election are political parties, not individuals (candidates). By giving the legal position to the candidates to directly submit a dispute against the KPU/KPUD, it appears that this dispute resolution system wants to adjust to the open list proportional electoral system. That is when voters are given the opportunity to elect candidates directly and the majority of votes determine the electability, the candidates are also allowed to submit election administrative disputes directly to the court.

Related to the mechanism of election administrative dispute resolution, Law 8/2012 requires that an election administrative dispute can be made after administrative efforts have been made at the Election Oversight Body (Bawaslu). With this regulation, political parties or legislative candidates cannot directly file a lawsuit to PTTUN. They must make efforts to resolve in Bawaslu first. After Bawaslu issues a decision, political parties or legislative candidates who still feel disadvantaged, can file a lawsuit to PTTUN.

The claim is must be made no later than 3 working days after the issuance of a Bawaslu decision. Dispute resolution by PTTUN is limited to a maximum of 21 working days since the claim is declared complete. After PTTUN issued a ruling, those who objected, are given the opportunity to make a final legal effort, namely an appeal to the Supreme Court. The Supreme Court's decision is final and binding, and no remedy could be taken. KPU is obliged to obey and follow up on the PTTUN's decision or the Supreme Court's decision once it has permanent legal force, no later than 7 working days after the decision has permanent legal force. 
In examining, adjudicating, and resolving disputes in the administration of the election, a special assembly is formed consisting of special judges who are career judges within the state administrative court and the Supreme Court. Judges who will resolve election administrative disputes are determined in advance by the Decision of the Chief Justice of the Supreme Court. In addition, there are also minimum terms of service for the special judge, which is a minimum of three years in office. However, there is an exception that the minimum terms of a 3-year term can be ruled out if there are no judges who meet these qualifications. in the court of law who will resolve the administrative dispute of the electoral state. The judges must also know about the election.

In the 2019 elections, the role of the administrative court in resolving disputes in the electoral process was further strengthened. This is regulated in Article 470 of Law 7/2017. The scope of electoral process disputes, including disputes arising in the field of election administration between candidates for members of the DPR, DPD, Provincial DPRD, Regency/City DPRD, or political parties participating in the election, or prospective pairs of candidates with election commission as a result of the issuance of decision of commission.

In contrast to the 2014 elections where the judicial authority was PTTUN, in the 2019 election the authority to settle disputes over the electoral process was left to the State Administrative Court (PTUN) or the first level of the administrative court. In addition, there are 3 (three) KPU decisions that can be reviewed at PTUN. First, the KPU's decision regarding the determination of political parties participating in the election. This means that the party in this dispute is the KPU and the political parties (election participant candidate) which are declared not pass the verification. Second, the KPU's decision regarding the determination of presidential and vice-presidential candidates. In this case, the party in this dispute is the $K P U$ with a pair of candidates for president and vice president who are declared not pass the verification. Third, the KPU's decision regarding the determination of the list of permanent candidates for members of the DPR, DPD, Provincial DPRD and Regency/City DPRD, including the matter of removing the legislative candidates from the candidate list. In this context, the parties to the dispute are the KPU with candidates for the $D P R, D P D$, Provincial DPRD and Regency/City DPRD candidates. However, prior to the submission of the dispute to the Administrative Court, there are the same conditions as stipulated in Law 8/2012, namely, the plaintiff must go through the administrative dispute process first in Bawaslu.

The claim to PTUN is submitted no later than 5 days after the Bawaslu Decision is made. PTUN is given a maximum of 21 working days since the claim is declared complete to issue a decision. PTUN Decisions are final and binding. $K P U$ is obliged to follow up on PTUN's decision no later than three working days. This is different from the regulation of Law 8/2012 where it is possible to submit an appeal to the Supreme Court.

Judges who will handle disputes over the electoral process are judges within PTUN on condition that they have served their duties for at least 3 years. During 
handling the dispute, the judges are acquitted of other cases. In addition, there are general requirements, the judges must have knowledge about the election.

Based on the description above, it appears that PTUN's involvement in handling election administration disputes began in the 2014 elections through the legal regime of Law 8 of 2012. Unlike the previous elections (1999, 2004 and 2009), where the election dispute resolution is directly handled by the Supervisory Committee. This election watchdog has in some ways a quasijudicial function. PTUN's involvement in resolving election administration disputes strengthens the dispute handling system in the implementation of elections. The role of the Administrative Court complements the functions of the Bawaslu and the Constitutional Court.

However, there are differences between the 2014 and 2019 elections. In the 2014 elections, the court that was given the authority to resolve election administration disputes was PTTUN. The verdict is not final and binding, so the parties can still be appealed to the Supreme Court. While in the 2019 elections, the authority was given to PTUN with the nature of the final and binding decision. No further remedies can be made. The flow of dispute handling has become shorter and more effective. Regarding the scope of the dispute is relatively the same. The object of the lawsuit is only the KPU's decisions relating to the participation of political parties, pairs of candidates, and legislative candidates.

\section{The Analysis of PTUN Decision on Election Process Dispute}

\section{Participation of the Indonesian Unity Justice Party (PKPI) in the 2019 Elections (Decision No. 56/G/SPPU/2018/PTUN-JKT)}

The Election Commission issued Decree Number No. 58/PL.01.1-Kp/03/ KPU/II/ 2018 dated February 17, 2018, about the determination of political parties participating in the 2019 Election. In this decision, the Indonesian Justice and Unity Party (PKPI) was declared ineligible to participate in the election because PKPI does not fulfill the requirement to have office domicile, management and number of members with a minimum of $75 \%$ of the total districts or cities of each province in Indonesia. PKPI does not meet the requirements in four provinces: West Java, Central Java, East Java, and Papua.

Because of objections to the KPU's decision, PKPI submitted a dispute to Election Supervisory Body (Bawaslu). The decision of Bawaslu strengthens the KPU's decision, namely PKPI does not qualify as an election participant. Still not accepting the decision of Bawaslu, PKPI filed a lawsuit for the election administration dispute to the Jakarta Administrative Court (PTUN). The Jakarta Administrative Court stated that the KPU was wrong in issuing a decision on the determination of political parties participating in the election. Therefore, the $K P U$ 's decision stating that PKPI did not meet the requirements was asked to be revoked and PTUN ordered the KPU to designate PKPI as an election participant.

One of the principles of the election is that each party related to the implementation of the election must work in accordance with the legal framework for elections that have been made and agreed upon together. In carrying out the 
legal framework, election administrators will be able to determine the fulfillment of citizens' voting rights. In the context of the PKPI case, it is related to the right to be elected in the elections. KPU as the organizer of the election must be fair to all party candidates in the election. The KPU should accept anyone who wishes to register to be an election participant, then later to examine, and to verify its requirements, as stipulated in the Election Law. For PKPI as a candidate for election participants, it is obligatory to fulfill the conditions stipulated in the election law, because this requirement applies to all parties that want to become an election participant.

This means that both the KPU as the organizer of the election and the PKPI as a political party as the candidates for the election participant must comply with the legal framework of the election and fulfill all the requirements. In the procedure of registration for candidates participating in the election 2019, there was a KPU decision no. 5/PL.01.1-Kp/03/KPU/II/2018 about the determination of political parties participating in the 2019 election. In this decision, PKPI was declared ineligible as an election participant. According to Law No. 7/2017, there are two levels of legal remedies that can be conducted by PKPI to challenge the KPU's decision.

First, submit a dispute on the electoral process to Bawaslu. In this case, PKPI has filed a dispute to Bawaslu with case registration Number 12/PS-REG2/ BAWASLU/II/2018 dated March 6, 2018. In its decision, Bawaslu refused the reasons and objections raised by PKPI against the KPU's decision. Bawaslu said that the process of registering and verifying the nomination of political parties participating in elections by the KPU was in accordance with the election law. PKPI was declared not eligible as an election participant. The KPU's decision that stated PKPI did not qualify as an election participant was published after the factual verification of political parties, which found that PKPI did not qualify as a candidate for the election candidates in 73 districts / cities spread across 4 provinces. The details, namely in East Java Province, PKPI does not meet the requirements in 15/cities. Then in Central Java Province, PKPI did not meet the requirements in 26 districts/cities. Then in West Java Province, PKPI did not meet the requirements in 15 districts/cities. Finally, in the Papua Province, PKPI also does not meet the requirements in 17 districts/cities.

The conditions that cannot be fulfilled by PKPI are the domicile of offices that do not meet the requirements, the list of management, and the number of members that are not in accordance with what is regulated in Law Number 7 of 2017. The law states that, political parties that want to participate in the election must have office domicile, management structure, and a minimum membership number of 1000 or $1 / 1000$ at the district/city level. This number must be met by political parties in 34 provinces. Each political party has a minimum office domicile, management structure, and membership in $75 \%$ of the total city/ districts in 34 provinces. With the verification results above, of course, PKPI does not meet the requirements, because it does not meet the minimum requirements in $75 \%$ of districts/cities in East Java, West Java, Central Java, and Papua. 
Second, because Bawaslu rejects claims submitted by PKPI, PKPI can take the next legal effort by filing an election process dispute to the Jakarta Administrative Court. In the lawsuit to the Jakarta PTUN, the argument filed by PKPI was, that the KPU did not obey the principles in carrying out its duties as the organizer of the election, namely the principles of self-reliance, honesty, fairness, legal certainty, orderly, transparently, proportionally, professionally, accountably, effectively, and efficient.

PKPI said that the KPU violated the principles of legal certainty, openness, and professionalism in organizing elections. Another argument presented was that, for several regencies/cities that were used as objects of the lawsuit, PKPI said, it should be the KPU who came to party members one by one, and not political parties that had to bring their members to the KPU's office. Another argument submitted by PKPI is that KPU does not involve Bawaslu in the registration and verification and determination of political parties participating in the 2019 Election. In addition, the KPU is considered to be inaccurate, inefficient, and ineffective, and not accountable related to the issue of the conditions for women's representation in the management of the political party.

In its answer, the KPU explained the lack of conditions experienced by PKPI. To be a participant in the 2019 elections, political parties must have offices and management in 34 provinces. Meanwhile, from 34 provinces political parties must also have offices, management, and membership at least $75 \%$ of the total number of regencies/cities in each province. Related to this requirement, for the Province of West Java, each political party must have a minimum office domicile, management and members in 21 regencies/cities. Meanwhile, PKPI only submitted administrative requirements in 20 regencies/cities. Of the 20, 2 regencies that do not meet the requirements, namely Bandung and Indramayu, and 1 city, namely Bekasi City.

The KPU also attached a Bawaslu Decision related to the argument raised by PKPI related to conditions in Jayapura Regency, which said that the KPU had never conducted factual verification of the PKPI requirements file in Jayapura Regency. With regard to this argument, it was revealed in the facts of the Bawaslu trial that verification was not carried out because PKPI had never submitted the required documents to be verified factually. This means that from the beginning, PKPI did not meet the administrative documents as election participants for Jayapura Regency. The same thing also happened in Yahukimo Regency. PKPI has never submitted a list of members to be verified by the KPU. Even after being extended, PKPI did not make any improvements. For this reason, PKPI was declared ineligible in Yahukimo District.

In its consideration, the PTUN panel of judges focused on answering the issue of whether the KPU in issuing decisions was in accordance with the prevailing laws and regulations and general principles of good governance. Then, the PTUN judge also stated that they would consider this case with the ex tunc principle, namely testing an administrative decision by looking at the laws and regulations that were in force at the time the decision was issued. In their 
consideration, the PTUN judge said that the KPU was inconsistent in issuing a decision stating that the PKPI did not qualify as an election participant, because it did not make the decision letter about PKPI having submitted administrative requirements as an election participant as consideration

According to the PTUN judge, there was an inconsistency when the KPU issued a letter receiving the submission of PKPI administrative documents as participants in the election, but another decision was issued stating that PKPI was declared ineligible. In this regard, PTUN judges do not carefully consider every election cycle, especially the verification cycle of the nomination of political parties as a participant of the election, which could lead to different legal consequences. In this context, PTUN judges should not conclude as simple as that. The Administrative Court Judge should also consider something far more important than the series of verification of political parties participating in the election, namely the factual verification of political parties. Even though it has met the complete administrative requirements, however when a factual check is made on the administrative file, it could have happened otherwise. That it turns out that the administrative requirements were not proven factually. In this case, PKPI has indeed submitted administrative requirements. However, when factual verification was done, it turned out that the administrative requirements were not proven factually in the field. Therefore, PKPI was declared ineligible

Then in the next consideration, the Jakarta Administrative Court judge also made an inaccurate conclusion. The KPU's decision was declared inappropriate because it was still guided by the Political Party Information System (SIPOL). The consideration of the Jakarta PTUN judge regarding the PKPI case was again inaccurate, because the reference used by the KPU in making decisions about parties that met the requirements or did not meet the requirements was no longer the administrative requirements submitted at the beginning. However, based on the results of factual verification in the field of all submitted administrative documents. This was not considered at all by Jakarta PTUN judges in their decision. In fact, the cause of PKPI failing to qualify as an election participant is the result of factual verification.

Then, related to the requirements that were not fulfilled in Central Java, the PTUN judge said that the KPU was not professional, because it asked PKPI official to make a letter of inability to meet the management, domicile, and membership requirements. The PTUN judge concluded that because of the initiative to make the letter from the KPU, the KPU was declared to be disproportionate and unprofessional. Meanwhile, in the facts of the trial, it was revealed that PKPI officials in Central Java were indeed unable to meet the conditions of domicile, management, and membership as election participants.

However, the logic of the PTUN judge jumped back and tended to be wrongly focused. The problem that was taken into consideration was who proposed the statement that PKPI was unable to meet the requirements. Because the one who proposed the letter was the $K P U$, so the $K P U$ was considered to be disproportionate and unprofessional. In fact, what is even more urgent 
and crucial to be considered by PTUN judges is whether the PKPI in factual verification of political parties participating in the election can meet the requirements stipulated in Article 173 paragraph (2) of Law no. 7/2017? The PKPI management in Central Java clearly stated that the PKPI was unable to meet these requirements

Then, for the Province of East Java, the panel of judges only considered the minutes of administrative recapitulation in only one district, namely Jombang Regency. In fact, the KPU verification results stated that PKPI did not meet the requirements in 15 districts/cities. What is considered by the Jakarta PTUN judges is not holistic and does not answer the main problem that should be reviewed by the PTUN judge. Then in its decision, the Jakarta Administrative Court stated that the KPU's decision was flawed in the procedure and granted all of the PKPI'S requests.

The essence of the election process dispute resolution in PTUN is to test the accuracy of the KPU's actions in verifying the requirements of election participants. In this case, the consideration of the PTUN panel of judges was very unbalanced and did not understand the context of the electoral cycle, especially the factual verification process that could have legal consequences for the political parties. The Jakarta Administrative Court decision also did not consider what had been decided by Bawaslu. Supposedly, what has been decided by the Bawaslu is reviewed by the Administrative Court, so that if the Administrative Court makes a decision that is different from the Bawaslu, then the Administrative Court judge can explain these differences with legal arguments and legal facts that are coherent, systematic and holistic.

The consideration of the Jakarta PTUN judge regarding the Bawaslu's decision is very important to maintain the continuity of the process, because the lawsuit at PTUN is the second attempt after the adjudication process in Bawaslu has been passed. Bawaslu's decision is also important because this institution supervises the entire series of factual verification of political parties. So PTUN can get complete and comprehensive information, but in this decision, the judge's judgment seems unbalanced, tends to seek justification to support the plaintiff's arguments, and do not understand the stages of the election.

\section{Oesman Sapta Odang's Nomination as a Candidate of the Regional Representative Council (DPD) Member in the 2019 Elections}

Oesman Sapta Odang (OSO) is the Chairperson of the Hanura Party, as well as serving as the Chairperson of the Regional Representative Council $(D P D)$. In the process of nominating DPD members in the 2019 elections, OSO again nominated himself as a DPD member from the electoral district of West Kalimantan. After going through the registration process, verification, the name of OSO entered into a provisional list of candidates for DPD members in the West Kalimantan electoral district determined by the KPU on July 19, 2018.

However, on July 23, 2018, the Constitutional Court (MK) read out the judgment ruling Article 182 Law No. 7 of 2017. In essence, the Constitutional Court provides an interpretation of "other work" phrases in the requirements 
to become a member of the DPD that may not be as management of a political party. After the Constitutional Court Decision was issued, the KPU changed the KPU Regulation No. 14 of 2018 became KPU Regulation No. 26 of 2016 whose material is in accordance with the decision of the Constitutional Court. This $K P U$ Regulation also regulates the conditions for submitting resignation letters for the management of political parties that have registered as DPD candidates for the 2019 Election.

Every political party management that has been determined in the provisional list of candidates, is required to submit a resignation letter before they are determined to be a permanent candidate list. On September 20, 2018, the $K P U$ decide the permanent candidate list. Until the deadline for the obligation to submit resignation letters, OSO did not submit them. Finally, the KPU did not add OSO name in the permanent candidate list. Objection to the KPU's decision, OSO submitted a dispute request to Bawaslu. On 11 October 2018, Bawaslu issued a verdict which essentially rejected the OSO lawsuit.

Because it was rejected by Bawaslu, OSO filed a lawsuit on an electoral process dispute to the Jakarta Administrative Court. In addition to suing the Decree on the determination of permanent candidate list of DPD by KPU to PTUN, OSO also submitted a review to KPU Regulation No. 26 of 2018 to the Supreme Court. The Supreme Court granted the judicial review submitted by OSO on October 30, 2019. The Supreme Court granted the judicial review submitted by OSO on October 30, 2019. In essence, the Supreme Court said that the requirement to resign as an official (management) of a political party contained in the KPU Regulation is a retroactive provision, so it is nullified. In fact, what is regulated by the KPU follows the Constitutional Court's decision that says the prohibition for political party officials (management) to become DPD candidates applies from the 2019 Election and beyond.

After the Supreme Court ruling on the judicial review of the KPU Regulation came out, the Administrative Court also issued a decision on November 14, 2018. In essence, the PTUN granted OSO lawsuit, and ordered to revoke the $K P U$ 's decision that did not contain the OSO name, and ordered KPU to issue a new decree containing the OSO name in the permanent candidate list. Having 3 different judicial institutions' decisions and all of them are binding for the KPU, the KPU finally took the stand by sending a letter to OSO to immediately submit his resignation letter as Hanura party official to the KPU no later than December 21,2018 . However, until that time, OSO has not submitted resignation letters to the KPU. The KPU finally did not include OSO name in the permanent candidate list. The action of the KPU which asked OSO to resign from the political party was reported as administrative violations to Bawaslu. On January 9, 2019, Bawaslu ordered the KPU to include OSO name in the permanent candidate list. However, OSO is required to resign as political party management when later elected.

This Bawaslu decision is certainly not in accordance with the Constitutional Court ordered. The Constitutional Court's ruling in July 2018 decided that every 
political party official has to be resigned at the time of nomination, not after they are elected. Finally, the KPU still did not include OSO name in the permanent candidate list and OSO did not participate in the 2019 election because he did not want to resign as the Chairman of Hanura party.

The decision of the Supreme Court is the beginning of the occurrence of a mistake about whether or not a party official can be nominated as a candidate for DPD member. The Supreme Court in its ruling annulled KPU regulations which obliged party officials to resign when nominating themselves as candidates for DPD members. This Supreme Court decision was later adopted by the PTUN, that the KPU must add the OSO name in the list of permanent candidates for $D P D$ members. In connection with this fact, the two judicial institutions, the Supreme Court and the Administrative Court have made a mistake in deciding this case, based on the following reasons.

Firstly, the Supreme Court failed to comprehend holistically the Constitutional Court's decision No. 30 / PUU-XVI / 2018 which ordered that the management of political parties no longer be able to nominate themselves as members of the DPD. The Constitutional Court's decision explicitly states that this decision applies to the 2019 and subsequent elections. The Court provides a way out for party officials who have been registered in the provisional list of candidates. The procedure is to resign from the party management and submit the resignation letter to the KPU. For those who have resigned from the management of the party, they can be determined to be a candidate for $D P D$ member (in the permanent candidate list). The Court's ruling was later followed by the KPU.

Secondly, the Supreme Court failed to understand the final and binding nature of the Constitutional Court's decision. This failure can be seen from the Supreme Court's ruling that the resignation as a political party official is a new requirement and should not be applied retroactively to candidates for $D P D$ members who have entered into the provisional list of candidates. In other words, the Supreme Court wants to state that the terms of resignation from political parties do not yet apply to the 2019 elections, but the next elections. In fact, this requirement is not applied retroactively, because the DPD member nomination process has not yet been completed, there is still a further stage after making a provisional list of candidates, namely establishing a permanent candidate list. This permanent list of candidates will be used in the election. In the Constitutional Court's decision, it was clearly stated that the conditions of resignation from political parties must be completed before the establishment of a permanent candidate list.

Thirdly, in line with the Supreme Court, the Jakarta Administrative Court also did the same thing. In deciding the validity of the decision issued by the $K P U$, the Jakarta Administrative Court only refers to the Supreme Court's Decision, without considering the Constitutional Court's decision. Whereas the Constitutional Court's decision should be the reference, because the Constitutional Court's decision is a constitutional interpretation of a regulation. 
When the Court has decided something, then other institutions, including the judiciary, should follow the decision. However, in the OSO case, the Administrative Court did not consider the Constitutional Court's decision. As a result, the PTUN ruling used the same legal considerations as the Supreme Court ruling and ordered the KPU to continue to include OSO in the 2019 election. What was ordered by the PTUN was certainly contrary to MK's order.

Fourthly, the Supreme Court and PTUN decisions have caused legal uncertainty. KPU as the organizer of the election will be confused to respond to court decisions that differ from one another. However, at the same time, all court decisions are final and binding for the KPU. This legal uncertainty was created by the Supreme Court's and PTUN's decision that contradicted the Constitutional Court's decision. The Supreme Court and the Administrative Court should have referred to the Constitutional Court's decision because the Constitutional Court had given a constitutional interpretation of the issue of whether DPD candidates had to resign from the management of political parties. The constitutional interpretation should be referred by the Supreme Court and the Administrative Court in deciding this issue.

Fifthly, it appears that the judges, both in MA and PTUN, do not understand well about election regulations. The legal argument that was built in the controversial decision shows that the judges did not fully understand the electoral regulations and the procedures for conducting the elections. This is illustrated from the perspective of the judges about the provisional list of candidates which seemed to be considered as a permanent candidate list. Though both have fundamental differences. The list of candidates to be used for elections is a permanent candidate list, not the provisional candidate list.

\section{Conclusion}

Firstly, regarding the development of the authority of the State Administrative Court in resolving disputes over the electoral process. The involvement of the administrative court in general elections, especially for administrative disputes, has only begun in the legal regime through Law No. 8 of 2012. This means that out of the five elections held in Indonesia since the reform, the resolution of the election process dispute involving the administrative court has only been conducted in two elections, namely the 2014 and 2019 elections. The court levels involved in the 2014 elections are PTTUN (Administrative High Court). PTTUN's decision can be appealed to the Supreme Court. This arrangement is different from the provisions in the electoral legal regime for the holding of the 2019 elections, namely Law no. 7 of 2017. In this Law, the level of court that is given the authority to resolve election administration disputes is the Administrative Court (first instance administrative court). PTUN Decisions are final and binding decisions, and there is no room for legal remedies.

The forms of disputes that can be submitted to PTTUN and PTUN are also limited. If it is simplified, only KPU decisions related to the participation of political parties, pairs of candidates, and legislative candidates can be submitted to PTTUN and PTUN. This means that only KPU decisions are directly related to the right to be elected as 
election participants which can be submitted to the state administrative court. Whereas the Election Law specifically regulates the legal issues for resolving disputes in the electoral process. The alignment effort at PTUN can be carried out after the parties have taken administrative efforts at Bawaslu. Filing a claim may only be submitted by election participants. Submission and resolution of disputes are limited by a certain time. In examining, adjudicating, and resolving disputes over the electoral process, the Election Law mandates that a Special Assembly be formed consisting of special judges who are career judges within the state administrative court. Special judges are determined based on the decision of the Chief Justice of the Republic of Indonesia.

Secondly, related to the analysis of the court decision, this study found various fundamental weaknesses in the decision. The weakness is related to the judge's understanding of the electoral system and the stages of the election implementation. It appears that judges do not really understand the substance of regulations, systems and technical aspects of elections, for example concerning the verification of political parties. The lack of understanding of the judge can be seen from the legal considerations used by the judge in their decision. In fact, several irregularities were found in the legal considerations used by the judges.

\section{Suggestion}

Based on the results of the study, the following suggestions can be submitted. Firstly, it is necessary to improve regulations regarding the resolution of disputes in the electoral process. These improvements are related to the plaintiff or the petitioner, that the KPU or KPUD as the state administrative body or agency that determines the decision should be given the right to make an "appeal" against the Bawaslu's decision.

Secondly, it is necessary to improve the rules regarding administrative efforts in Bawaslu. These administrative efforts are not clearly regulated in the election law. As a result, there are different interpretations of administrative efforts that should have been taken before filing a lawsuit with the Administrative Court.

Thirdly, it is necessary to examine PTUN decisions related to election process disputes. There are various cases and various approaches used by judges to settle a case. The diversity of decisions can be good, in the sense that there are many references can be used by election organizers as a future reference, but it can also be bad meaning when the diversity of decisions turns out to show that PTUN makes their own interpretations that differ from the intent of the provisions of the election law. Examination results of the decision can be used as material for recommendations for improvement of the Election Law in the future.

\section{BIBLIOGRAPHY:}

\section{Books:}

F. Sugeng Istanto. (2007). Penelitian Hukum. Yogyakarta: Ganda. Janedri M. Gaffar. (2013). Demokrasi dan Pemilu di Indonesia. Jakarta: Konstitusi Press.

\footnotetext{
382 Yustisia Volume 8 Number 3 (Sept.-Dec. 2019) The Authority of Administrative Court...
} 
Jimly Asshiddiqie, Gagasan Kedaulatan Rakyat dalam Konstitusi dan Pelaksaannya di Indonesia Pergeseran Keseimbangan Antara Individualisme dan Kolektivitisme dalam Kebijakan Demokrasi Politik dan Demokrasi Ekonomi Selama Tiga Masa Demokrasi, 1945-1980-an, 1994, PT Ichtiar Baru Van Hoeve, Dalam Khairul Fahmi. (2012). Pemilihan Umum \& Kedaulatan Rakyat, Ed.1 Cet.2, Jakarta: RajaGrafindo Persada.

Jimly Asshiddiqie. (2013). Menegakkan Etika Penyelenggara Pemilu. Jakarta: Rajawali Pers.

Mukthie Fadjar. (2013). Pemilu, Perselisihan Hasil Pemilu dan Demokrasi. Malang: Setara Press.

Mukti Fajar dan Yulianto. (2010). Dualisme Penelitian Hukum Normatif dan Empiris. Yogyakarta: Pustaka Pelajar.

Ni'matul Huda. (2012). Ilmu Negara. Jakarta: Rajawali Pers.

Peter Mahmud Marzuki. (2011). Penelitian Hukum. Jakarta: Kencana.

Refly Harun. (2016). Pemilu Konstitusional, Desain Penyelesaian Sengketa Pemilu Kini dan ke Depan. Jakarta: Rajawali Pers.

Ranjit Kumar. (1999). Research Methodology: a Step-by-Step Guide for Beginners. Melbourne: Addison Wedley Longman Australia Pty. Limited.

Soerjono Soekanto dan Sri Mamuji. (2001). Penelitian Hukum Normatif (Suatu Tinjauan Singkat). Jakarta: Rajawali Pers.

Topo Santoso. (2015). Penegakan dan Penyelesaian Masalah Hukum dalam Pemilihan Umum Serentak. Jakarta: PT Radja Grafindo Pesada.

Willibrordus Riawan Tjandra. (2009). "Fungsi Peradilan Tata Usaha Negara dalam Mendorong terwujudya Pemerintahan yang Bersih dan Berwibawa (Clean and Strong Government)". Yogyakarta: Disertasi Program Pascasarjana Fakultas Hukum Universitas Gadjah Mada.

\section{Journals:}

Didik Sukriono. (2009). Menggagas Sistem Pemilihan Umum. Jurnal Konstitusi PKK Universitas Kanjuruhan Malang Volume II Number 1, Juni. Jakarta: Mahkamah Konstitusi Republik Indonesia,

Khairul Fahmi. (2015). Sistem Penanganan Tindak Pidana Pemilu. Jurnal Konstitusi, Volume 12, Number 2.

\section{Legal Documents:}

1945 Constitution of The Republic of Indonesia

Law Number 5 of 1986 on Administrative Court

Law Number 3 of 1999 on Elections

Law Number 23 of 2003 on President and Vice President Elections 
Law Number 10 of 2008 on Elections of The Members of The People's Representative Council, Local Representative Council, and People's Local Representative Council

Law Number 42 of 2008 on President and Vice President Elections

Law Number 51 of 2009 on The Second Amendment of Law Number 5 of 1986 on Administrative Court

Law Number 8 of 2012 on The Elections of Members of The People's Representative Council, Local Representative Council, and People's Local Representative Council.

Law Number 7 of 2017 on Elections

The Supreme Court Regulation Number 5 of 2017 on Procedures for Settling Disputes over the Election Process in the State Administrative Court.

The Election Supevision Body Regulation Number 8 of 2018 on Election Administration Violation Settlement.

The Election Supervisory Body Number 18 of 2017 on Procedures in Settling Disputes of The Election Process

Administrative Court Verdict Number 12 / G / 2013 / PT.TUN.JKT

Administrative Court Verdict Number 56/G/SPPU/2018/PTUN-JKT

Jakarta Administratve Court Verdict Number 242/G/SPPU/2018/PTUN-JKT 